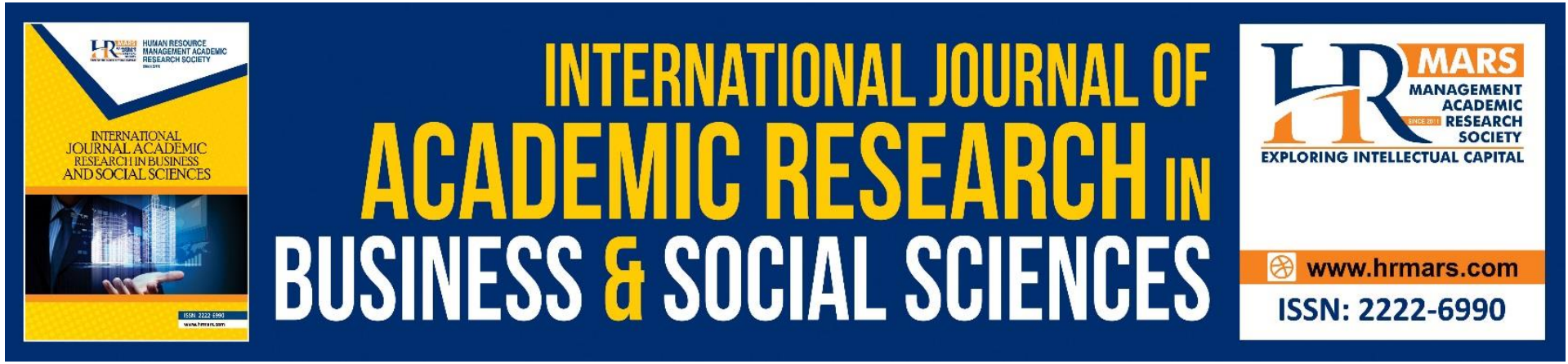

\title{
Analyzing Attitude of Halal Food Purchasing Among Muslim Millennial: A Malaysian Experience
}

Hainnuraqma Rahim, Mohamed Saladin Abdul Rasool, Nadiah Rus Liyana Rusli, Norkumala Awang

To Link this Article: http://dx.doi.org/10.6007/IJARBSS/v11-i8/10801

DOI:10.6007/IJARBSS/v11-i8/10801

Received: 07 June 2021, Revised: 12 July 2021, Accepted: 28 July 2021

Published Online: 09 August 2021

In-Text Citation: (Rahim et al., 2021)

To Cite this Article: Rahim, H., Rasool, M. S. A., Rusli, N. R. L., \& Awang, N. (2021). Analyzing Attitude of Halal Food Purchasing Among Muslim Millennial: A Malaysian Experience. International Journal of Academic Research in Business and Social Sciences, 11(8), 1124-1135.

Copyright: @ 2021 The Author(s)

Published by Human Resource Management Academic Research Society (www.hrmars.com)

This article is published under the Creative Commons Attribution (CC BY 4.0) license. Anyone may reproduce, distribute, translate and create derivative works of this article (for both commercial and non-commercial purposes), subject to full attribution to the original publication and authors. The full terms of this license may be seen at: http://creativecommons.org/licences/by/4.0/legalcode

Vol. 11, No. 8, 2021, Pg. 1124 - 1135

Full Terms \& Conditions of access and use can be found at http://hrmars.com/index.php/pages/detail/publication-ethics 


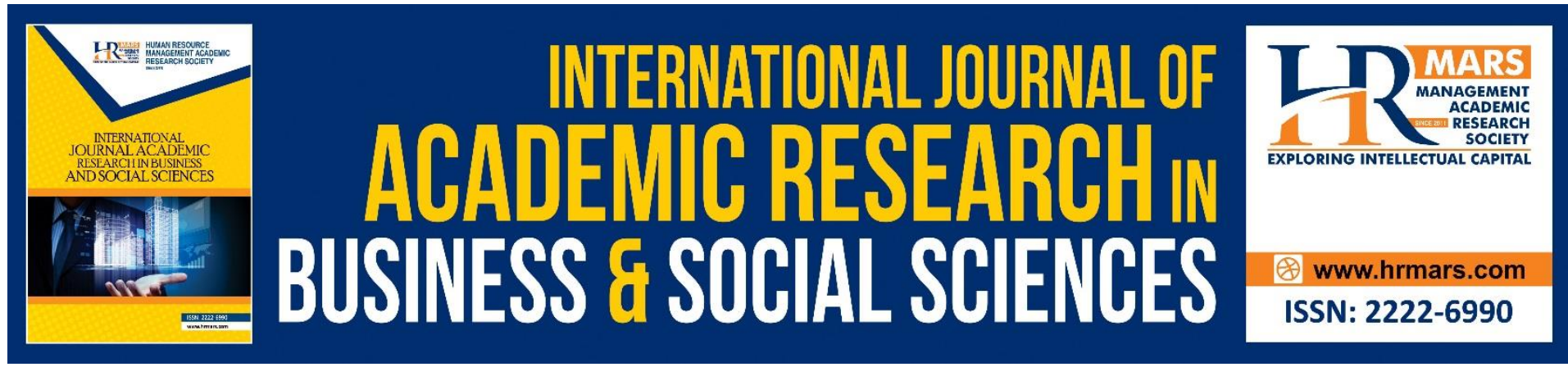

\title{
Analyzing Attitude of Halal Food Purchasing Among Muslim Millennial: A Malaysian Experience
}

\author{
Hainnuraqma Rahim, Mohamed Saladin Abdul Rasool \\ Faculty of Business and Management, Center for Islamic Philanthropy and Social Finance \\ (CIPSF), Universiti Teknologi MARA (UiTM), Cawangan Melaka, KM 26, Jalan Lendu, 78000 \\ Alor Gajah Melaka \\ Email: hainnuraqma@uitm.edu.my, saladin@uitm.edu.my
}

\section{Nadiah Rus Liyana Rusli}

Research and Development Division, Malaysian Research \& Education Foundation, 10-2, Jalan Dataran Jade, 2, Lingkaran Bandar Puncak Utama, Jade Hills, 43000 Kajang, Selangor

Email: nrusliyana@gmail.com

\section{Norkumala Awang}

Centre for the Science and Environment Studies, Institute of Islamic Understanding Malaysia, No2, Langgak Tunku Off Jalan Tuanku Abdul Halim, 50480 Kuala Lumpur, Malaysia

Email: norkumala@ikim.gov.my

\begin{abstract}
The Millennial generation is a potentially profitable target consumer group as they are financially independent and highly capable in accessing information and using the latest technology. Apart from being loyal to brands, they are very receptive to diversity, greatly independent and optimistic. Their attitudes indicate they are very concerned with quality assurance, diverse product and service selections and consumer rights. Attitude is a factor that frequently influences consumers' choice in selecting food products. Since the Millennials are a group of consumers that are sophisticated and extremely capable of making choices, it is pivotal to understand their attitude in selecting halal food. Provided that halal food consumption is critical in shaping a Muslim's personality. This study examined the factor of attitude among Muslim Millennials when purchasing halal food. This quantitative study applied the non-probability sampling method on 403 respondents using the SPSS version 26. Findings showed that when purchasing halal food products, factors such as halal understanding, halal logo, and religion were significant and have positive influences towards attitude of halal food purchase among Muslim Millennial generations. However, it was also found that the factor of social media influencer was not significant to the millennials. It is hoped that the findings of this study could contribute to assist in developing a marketing theory related to behavior towards halal food products.
\end{abstract}


Keywords: Attitude, Halal Products, Purchase, Millennial, Muslim, Quantitative Study

\section{Introduction}

Halal food industry has a good potential market. Current reports from the State of the Global Islamic Economy for the year 2020and 2021, stated that Muslims had spent \$2.02 trillion dollars across the sectors for food, pharmaceutical, cosmetics, fashion, travel and media and recreation in 2019, all of which were steered by the Islamic faith-inspired ethical consumption needs. In contrast, previously in 2010, Muslim's consumers accounted for only approximately $23 \%$ of the global population, and in 2050, Muslim consumers are expected to increase to $30 \%$ in population. In addition, the global population is projected to increase by $35 \%$ by 2050 , and essentially the Muslim population is anticipated to reach about $73 \%$, which is more than double the global population growth rate.

Current data also showed that in 2020, the global halal food market was US\$ 1.9 trillion dollars. As reported in the State of the Global Islamic Economy Report for the year 2020/21, the expenditure of Muslim consumers is projected to reach $\$ 2.4$ trillion by 2024 especially for food consumption. Fortunately, this means that there would be a significant boost of US\$ 1.38 trillion demands for halal food products. Moreover, Malaysian population has increased by 0.4 percent of population growth rate per year, from 32.5 million, in 2019 to 32.7 million in 2020. Significantly, the millennial generation makes up $29 \%$ of the total population. Millennial generation is defined as individuals who were born between the 1980s and the 2000s. They are distinguished by the following characteristics: preference for information search and fact finding via digital devices, owners of at least one or several social media accounts, have greater fondness for a smart phone over a television, and emphasize their decision-making based on family needs.

Essentially, the Millennial generation digital habits enable them to obtain information about halal food products through online digital platforms. This generation is faster and more open to receive and absorb the most recent information or news updates, which marketers could use to carry out social media marketing strategies (McCormick, 2016). For example Instagram, YouTube and Facebook platforms are used by marketers and sellers to market their products and services. Thus, this study intends to examine the attitude and behavior of Muslim Millennials in Malaysia particularly on how they generate their purchases. It is hoped that the outcome of this paper could contribute towards providing insights into the attributes that could possibly influence the generation of their purchases. Consequently, this information might offer valuable feedback for the Halal product producers on how to enhance the marketability of their products, and not just relying on Halal certification, as an ultimate saleable marketing point.

Generally, the presentation of this paper is organized as follows. Section 2 highlighted the meaning theory underpinning this study, and reviewed previous studies on factors such willingness, information and interest towards of Halal products, particularly among the millennial generation. Next, Section 3 presented the research methodology. After that, Section 4 discussed the findings of the empirical results. Finally, Section 5 concluded the paper. 


\section{Literature Review \\ Attitude}

Generally, attitude is a person's degree of favorable or unfavorable evaluation of the behavior (Ajzen, 1991). A person's attitude is characterized as a detailed assessment of a concept. In addition, a person's attitude towards Halal food is derived from their assumption that the food is Halal, and this belief could lead to favourable attitude such as the desire to buy the product (Ajzen, 1991). Attitude is also defined as a general assessment of a certain activity that reveals how much someone enjoys or dislikes doing it (Nico et al., 2021). Essentially, a Muslim's attitude on halal food leads to moral assessment in consumption activities (Maichum et al., 2017). In this study, the term "attitude" is defined as the level of respondents' liking for halal food products; consequently, factors which influenced the attitude of consumers towards purchasing halal product were investigated.

\section{Halal Understanding and Attitude of Halal Food Products Purchase}

In the context of halal food, personal understanding towards a particular product attraction is based on experience and information obtained about the food permitted in Islam (Kamarulzaman \& Ahmad, 2020). Lack of knowledge, awareness and understanding of the Halal concept among Muslims and the manufacturers of Halal products might cause the loss of appreciation towards the concept of Halal. In fact, the Quran stated that the search for Halal is not just for Muslims, but Halal concept is for the safety and benefit of all man kinds. Ultimately, individuals should understand that Halal means that food and products are prepared in the most hygienic manner, which essentially fulfilled the international food safety standards. This means that the Halal concept should not be viewed as offensive to any religious beliefs. In brief, the fundamental issues in the Halal food production include cleanliness, being free from 'contamination' and deemed as healthy food as defined in the Quran (Baharuddin et. al, 2015), which then leads to the following hypotheses:

H1: Halal understanding has a positive influence towards the attitude of purchasing halal food products among Muslim Millennial generation.

\section{Halal Logo and Attitude of Halal Food Products Purchasing}

Today's food quality paradigm is expanding which may result to the challenging tasks of verifying the credible qualities of a healthy food (Del Giudice et al., 2018). People are motivated to buy certain products because of certain factors such as whether the products are readily accessible and whether there are enough provisions of accurate information about the products (Abdul et. al, 2016). In fact, the Halal logo is a certification issued by acknowledged halal foundation for halal products which includes food items or even the businesses themselves. Moreover, the intentions of Muslims to acquire halal food have increased the trademark values and also boosted awareness towards halal food (Haque et al., 2015), which then leads to the following hypotheses:

H2: Halal logo perception has a positive influence towards attitude of purchasing halal food products among Muslim Millennial generation. 


\section{Social Media Influencer and Attitude of Halal Food Products Purchasing}

Social media influencers are third-party endorsers who could shape the generations' attitudes and also assist company marketing (SMIs) (Abdullah et. al, 2020). They are also known as micro-celebrities (Khamis, Ang \& Willing, 2016) or modern-day opinion-makers (Abdullah et. al, 2020). Influencers usually have a huge number of followers, and they advertise goods via appealing social media network site contents to attract their followers who come from certain generations stages (Sharma \& Ranga, 2014).

Currently, most generations believe in social media influencers rather than the selling points made through paid advertisements channels (Abidin, 2016). Moreover, the consumers today also have more positive attitude and intention towards products endorsed by expert social media influencers rather than amateur social media influencers (Rollins et. al, 2015). These influencers' marketing efforts normally extends throughout the brand creation process because they are considered as role models who have positive influence on their audiences (Sudha \& Sheena, 2017), which then leads to the following hypotheses:

H3: SMI has positive influence towards attitude of purchasing halal food products among Muslim Millennial generation.

\section{Religiosity and Attitude of Halal Food Products Purchasing}

Generally, the term "religion" refers to a vast variety of human behaviors, attitudes, beliefs, feelings, and experiences in relation to God or divinity (Ibrahim \& Hashanah, 2015). People who are religious have the tendency to obey religious laws and practices (Zakaria et al, 2017). The rise in religiosity has a considerable and positive impact on a generation's intentions to buy halal products. Many studies have shown that religion has significant effect on people's eating habits. In fact, the Muslim generations around the world are concerned about halal product issues which make the halal concept an important factor in determining their consumption behaviors.

Mathras et. al (2015)'s showed that religious elements were very important in influencing Muslims' food choices. Even though a Muslim is living in a non-Islamic culture and tradition, the teachings of Islam are still the basic guide of a Muslim's life especially in the aspect of halal food consumption. Current studies by Ali et. al (2021)'s and Sherwani et. al, (2018)'s demonstrated that religion may have a significant impact on a generation's food choices. The extent of their action, however, relies on the customer's strong faith in his or her religion, which then leads to the following hypotheses:

H4: There is a positive influence of religiosity towards attitude of purchasing halal food products among Muslim Millennial generation. 


\section{Methodology}

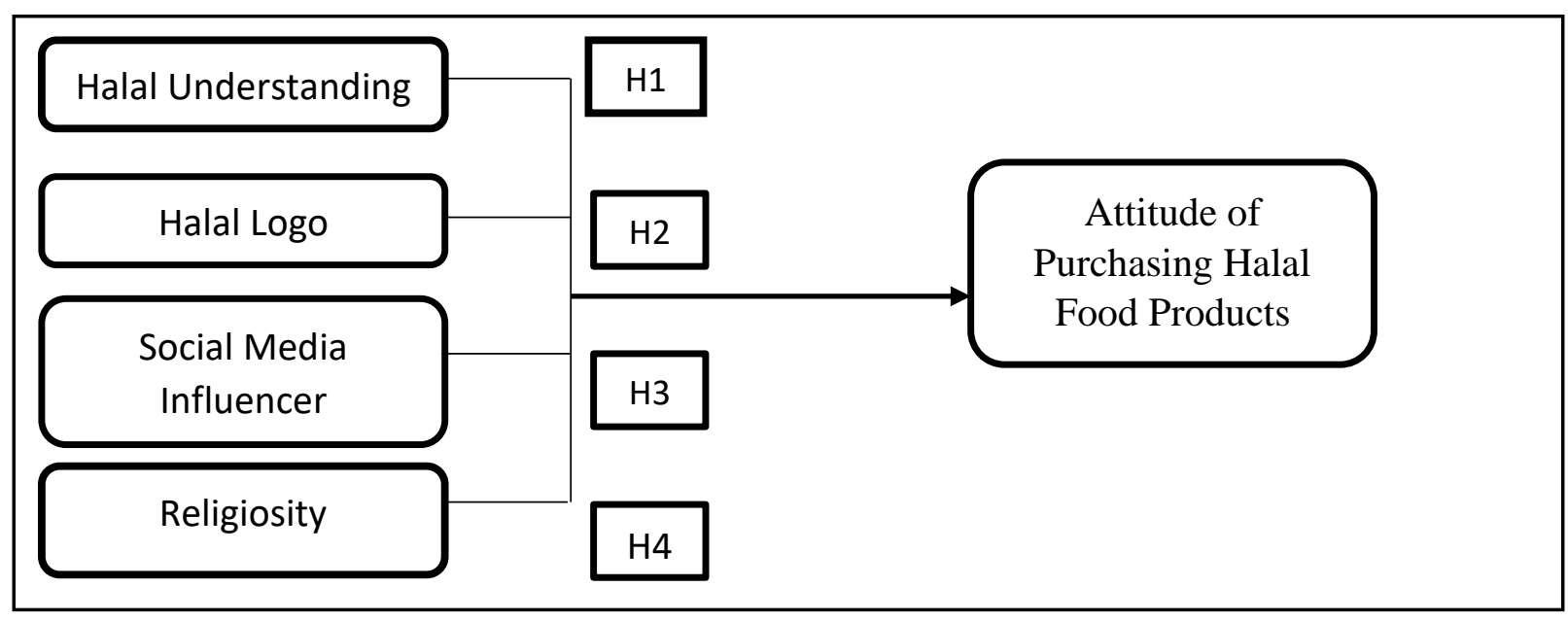

Figure 1: Theoretical Framework

This quantitative study employed a survey method for data collection. The deductive reasoning approach was used in this study to develop proposed hypotheses to design a hypothetical framework based on the improper well-established theory. The study used cross-sectional design as data collected from the respondents was obtained in a single period. Figure 1 describes the conceptual framework applied in this research which contained five variables, and every factor was calculated to use certain matters. All items were adapted from previous researches which contained 37 items with regards to items such as halal understanding, halal logo, social media influencer, religion and attitude. Halal understanding consisted of 12 items. Following that, religion was comprised of five things adapted from Muhamad, Leong, and Md Isa (2017). After that, attitude consisted of 10 items modified from Rusli (2021), and also Maichum, Parichatnon and Peng (2017). Halal logo consisted of 8 items modified from Hamidah and Nuraishah (2017). Lastly, social media influencer consisted of eight items modified from Billah et al, (2020).

In addition, this study aims to determine the factors which influence the purchasing behavior towards Halal food among the millennial generation group in Malaysia. In total, 455 questionnaires were distributed to the Millennial group aged between 18 and 38 years old (as indicated by the Global Islamic Economic Report, 2018; Millenial Generation Research Review, 2012) using the personal administered technique using the online and offline platforms due to the Covid-19 pandemic which has limited travelling and meeting instances. SPSS version 26 was used to estimate the results of analysis. Data obtained from the questionnaires were then analyzed using multiple linear regressions. The aim of this method was to test the interaction between halal understanding, halal logo, social media influencer and religion and attitude of purchasing halal food products in Malaysia.

The respondents who were from the Millennial generation were selected because they represented a significant amount which is $29 \%$, or an estimated of 852600 of the total population in Malaysia. In fact, the Millennial Generation is expected to continually increase by 0.4 percent each year. In addition, it is assumed that the Millennial Generation aged from 18 years old and above, would already have jobs; and therefore, this generation would possess the purchasing power and were able to make independent decisions in purchasing 
activities (Awang et. al, 2012). Thus, non-probability volunteer and convenience sampling methods were employed in the survey, since no sampling frame was available (Saunders et. al, 2012).

Out of the 455 questionnaires distributed, 403 questionnaires were used for analysis purposes. Each item was measured using the five points-Likert scale ranging from Scale 1 indicating strongly agree to Scale 5 indicating strongly disagree. There were various reasons for adopting the Five-Likert scale namely the response rate would improve using the fiveLikert scale as the respondents would fill up the questionnaires with honesty and devotion. Next, the five-Likert scale would help to reduce the respondents' frustration when compared to the seven or nine-Likert scales Bhatti et. al (2019)'s finally only recognized variables from previous research would be used to determine the constructs in the five-Likert scale (Khan et. al, 2020; Kraus et. al, 2020; Rehman et. al 2019; Rehman et. al, 2018).

\section{Result and Discussion \\ Respondent's Profile}

The descriptive analysis examined the demographic profile of each of the respondents. Based on the information presented in Table 1, the general profile of the respondents were 280 female respondents with $69.5 \%$, and the remaining were 123 male respondents, with $30.5 \%$. Most of the respondents were between the age of 19 and 23 years old, with $82.1 \%$ were still single, and $17.4 \%$ were married. Majority of the respondents have first degree education with $72.7 \%$, as their highest education level. The second highest group has Doctoral Degree education, with $12.65 \%$. Next, in terms of occupation, most respondents were working adults with $48.39 \%$ were on salaries, meanwhile the second largest group with $25.31 \%$, were selfemployed. 
Table 1: Respondent's Profile

\begin{tabular}{|c|c|c|}
\hline & Number $(\mathrm{N}=403)$ & \\
\hline Demographic Characteristics & Frequency & Percentage (\%) \\
\hline \multicolumn{3}{|l|}{ Gender } \\
\hline Male & 123 & 30.5 \\
\hline Female & 280 & 69.5 \\
\hline \multicolumn{3}{|l|}{ Age } \\
\hline $19-23$ years old & 108 & 26.79 \\
\hline $24-28$ years old & 125 & 31.02 \\
\hline $29-33$ years old & 73 & 18.11 \\
\hline $34-38$ years old & 97 & 24.07 \\
\hline \multicolumn{3}{|l|}{ Race } \\
\hline Malay & 363 & 90.1 \\
\hline Chinese & 28 & 6.9 \\
\hline Indian & 7 & 1.7 \\
\hline Others & 5 & 1.2 \\
\hline \multicolumn{3}{|l|}{ Marital Status } \\
\hline Single & 120 & 29.77 \\
\hline Married & 267 & 66.25 \\
\hline Widower/Widow & 16 & 3.97 \\
\hline \multicolumn{3}{|l|}{ Highest Education Level } \\
\hline SPM & 27 & 6.69 \\
\hline STPM/Diploma/A Level & 35 & 8.68 \\
\hline Bachelor's Degrees & 140 & 34.74 \\
\hline Master's Degrees & 116 & 28.78 \\
\hline Doctoral Degrees & 85 & 21.09 \\
\hline \multicolumn{3}{|l|}{ Occupation } \\
\hline Student & 45 & 11.17 \\
\hline Housewife & 36 & 8.93 \\
\hline Employee & 195 & 48.39 \\
\hline Self-employed & 102 & 25.31 \\
\hline Unemployed & 25 & 6.20 \\
\hline
\end{tabular}

Source: Primary Data

\section{Linear Regression Results}

Table 2 presented multiple linear regression results. Table 2 shows that variables such as halal understanding, halal logo, social media influencer and religion have positive correlations on the attitude of purchasing halal food products among the Muslim Millennial generation. 
Table 2: Results of Linear Regression

\begin{tabular}{lccc}
\hline \multicolumn{1}{c}{ Variables } & $\begin{array}{c}\text { Co-efficient } \\
\text { of regression }\end{array}$ & t-statistics & Significant \\
\hline Halal Understanding & 0.057 & 7.866 & 0.000 \\
Halal Logo & 0.061 & 5.615 & 0.000 \\
Religion & 0.080 & 3.599 & 0.000 \\
Social $\quad$ Media & 0.016 & 0.485 & 0.628 \\
Influencer & & & \\
Constants & 2.230 & & \\
$\mathrm{R}^{2}$ & 0.655 & & \\
F-statistics & 188.608 & & \\
Significant & 0.000 & & \\
\hline
\end{tabular}

Source: Authors' Computation Based on Primary Data

With regards to the data on the variables such as halal understanding, halal logo, and religion, the significant value showed 0.000 respectively. In addition, for the variables on social media influencer, the value showed 0.628. These results implied that using $\alpha=0.05$, the variables for halal understanding, halal logo, and religion were statistically significant affecting dependent variables partially, whereas social media influencer was insignificant. Meanwhile, the F-test has significance value of 0.000 or $\mathrm{P}<0.05$ which indicated that there was significant influence of halal understanding, halal logo, and religion towards the attitude of purchasing halal food products among the Muslim Millennial generation.

The coefficient of determination $\left(R^{2}\right)$ of regression result showed the value of 0.655 . This means that halal understanding, halal logo, and religion exposure accounted for only $65.5 \%$ towards the attitude of purchasing halal food products among the Muslim Millennial generation, while the rest, which was about 34.5\% came from other factors outside the model. This result implied the need for wider analysis on the other factors affecting Muslim Millennial generation's attitude of purchasing halal food products in Malaysia.

\section{Factors Influencing Muslim Millennial Attitude towards Halal Food Products}

The aim of this study was to investigate the factors which influenced Muslim Millennial generation's attitude in purchasing halal food products in Malaysia. The variables applied were Halal understanding, Halal logo, religion and social media influencer as independent variables and attitude in purchasing halal food products as the dependent variable.

The results for Hypothesis testing 1 showed that halal understanding has a significant positive influence towards the attitude of purchasing halal food products among the Muslim millennial generation. These results indicated that the level of Halal understanding significantly has a relationship with the attitude of purchasing halal food products in Malaysia. Moreover, the results from previous studies also supported this statement based on the study conducted by Muhamad et al (2017). Next, the results from Hypothesis testing 2 showed that Halal logo perception significantly has a positive influence towards the attitude of purchasing halal food products, which is relevant to the results from Ismail and Yunan (2016). In addition, the results from Hypothesis testing 3 showed that social media influencer was insignificant towards the attitude of purchasing halal food products among the Muslim Millennial generation. 
Nonetheless, these results contradicted with the study done by Ambali and Bakar (2014). Ambali and Bakar (2014) concluded that Muslim students in Yogyakarta acknowledged that they knew about halal products from the mass media platforms such as magazines and internet. Muslim students also obtained information about halal food through their friends from the social media platforms, and acknowledged that media has a major influence on their awareness of halal food. Therefore, the data of this study was also supported by the previous studies confirming the importance of media exposure towards halal product awareness. Media exposure is a potential source of information for the Muslim society to increase their awareness on consuming halal food. Finally, the results from Hypothesis testing 4 showed that religiosity significantly has a positive influence towards the attitude of purchasing halal food products among the Muslim Millennial generation, which is relevant to the study conducted by (Abd Rahman et. al., 2015; Garg \& Joshi, 2018).

\section{Conclusion}

Essentially, this study has significant contributions. It could be concluded that the Muslim millennials' attitude in purchasing halal food products in Malaysia were influenced by factors such as their understanding of the Halal concept, their perception of the Halal logo, and their level of religiosity. This study suggested that the purchase of halal food by Muslim millennials in Malaysia might be viewed as influenced by habit and purchase intention aspects, even if these factors might both be working independently. It is hoped that the outcome of this paper could contribute towards providing insights into the attributes that could possibly influence the millennial generation with regards to their purchases of food products. Consequently, this information might offer valuable feedback for Halal product producers on how to enhance the marketability of their products, and that they should not just rely on Halal certification, as an ultimate saleable marketing point.

Consequently, relevant Halal bodies and authorities in Malaysia should continue to educate and promote businesses in order to tap further into the Halal industries and motivate business owners in the local Malaysian and international market to obtain legal Halal logo certifications, especially from Halal Jakim Malaysia, which are widely recognized throughout the global world. In addition, dissemination of information regarding the importance of halal products from Sharia compliance perspectives should be continuously propagated to the public and business and entrepreneurial sectors. In fact, relevant digital and advance technologies and applications for marketing and business purposes should be employed with regards to the millennial generation group market.

\section{Acknowledgement}

This research was supported by the TEJA INTERNAL GRANT 2021 [Grant number: 600-TNCPI 5/3/DDN (04)(030/2021)], UiTM Cawangan Melaka.

\section{References}

Abd Rahman, A., Asrarhaghighi, E., \& Ab Rahman, S. (2015). Consumers and halal cosmetic products: knowledge, religiosity, attitude and intention. Journal of Islamic Marketing, 6(1). 148-163. https://doi.org/10.1108/JIMA-09-2013-0068.

Abdul Latiff, Z. A., Rezai, G., Mohamed, Z., \& Ayob, M. A. (2016). Food labels' impact assessment on consumer purchasing behaviour in Malaysia. Journal of Food Products Marketing, 22 (2), 137-146. 
Abdullah, T., Deraman, S. N. S., Zainuddin, S. A., Azmi, N. F., \& Abdullah, S. S. (2020). Impact of social media influencer on Instagram user purchase intention towards the fashion products: The perspectives of students. European Journal of Molecular \& Clinical Medicine, 7(8), 2589-2598.

Abidin, C. (2016). Visibility labour: Engaging with Influencers' fashion brands and \#OOTD advertorial campaigns on Instagram. Media International Australia, 161(1), 86-100. https://doi.org/10.1177/1329878X16665177.

Ajzen, I. (1991). The theory of planned behavior. Organizational Behavior and Human Decision Processes, 50, 179-211. https:// doi.org/10.1016/0749-5978(91)90020-T.

Ali, M. H., Iranmanesh, M., Tan, K. H., Zailani, S., and Omar, N. A. (2021). Impact of supply chain integration on halal food supply chain integrity and food quality performance. Journal of Islamic Marketing, ahead-of-print (ahead-of-print. https://doi.org/10.1108/JIMA-08-2020-0250.

Awang, A., Ahmad, Z., Subari, K. A., \& Asghar, A. R. (2010). Entrepreneurial Orientation among Bumiputera Small and Medium Agro-Based Enterprises (BSMAEs) in West Malaysia: Policy Implication in Malaysia. International Journal of Biometrics, 5, 130.130-143. DOI:, 10.5539/ijbm. v5n5p130.

Azam, A. (2016). An empirical study on non-Muslim's packaged halal food manufacturers: Saudi Arabian consumers' purchase intention. Journal of Islamic Marketing, 7(4), 441460. https://doi.org/10.1108/JIMA-12-2014-0084.

Baharuddin, K., Ahmad Kassim, N., Nordin, S. K., Buyong, S. Z. (2015). Understanding the halal concept and the importance of information on halal food business needed by potential Malaysian entrepreneurs. International Journal of Academic Research in Business and Social Sciences, 5 (2), 2222-6990. doi: 10.6007/IJARBSS/v5-i2/1476 URL: http://dx.doi.org/10.6007/IJARBSS/v5-i2/1476Bagozzi, R.P., \& Yi, Y. (1988). On the evaluation of structural equation models. Journal of the Academy of Marketing Science, 16, 74-94. https://doi.org/10.1007/BF02723327.

Bhatti, R., Rehman, S.-U., \& Chaudhry, N. I. (2019). Mediating effect of innovative culture and organizational learning between leadership styles at third order and organizational performance in Malaysian SMEs. Journal of Global Entrepreneurship Research, Springer; UNESCO Chair in Entrepreneurship, 9(1), 1-24. DOI: 10.1186/s40497-019-0159-1.

Billah, A., Rahman, M. A., \& Hossain, M. T. (2020). Factors influencing Muslim and non-Muslim consumers' consumption behavior: A case study on halal food. Journal of Foodservice Business Research, 23(4), 324-349. https://doi.org/10.1080/15378020.2020.1768040.

Elseidi, R. (2018). Determinants of halal purchasing intentions: Evidences from UK. Journal of Islamic Marketing,9 (1),167-190.

Freberg, K., Graham, K., McGaughey, K., \& Freberg, L. A. (2011). Who are the social media influencers? A study of public perceptions of personality. Public Relations Review, 37(1), 90-92. https://doi.org/10.1016/j.pubrev.2010.11.001

Garg, P., \& Joshi, R. (2018). Purchase intention of "Halal" brands in India: The mediating effect of attitude. Journal of Islamic Marketing, 9(3), 683-694. https://doi.org/10.1108/JIMA11-2017-0125.

George, D., \& Mallery, P. (2003). SPSS for Windows step by step: A simple guide and reference 11.0 update (4th ed.). Boston: Allyn \& Bacon.

Hair, J. F., Hult, G. T. M., Ringle, C. M., \& Sarstedt, M. (2017). A primer on partial least squares structural equation modeling (PLS-SEM) (2nd ed.). Thousand Oaks: Sage. ISBN-13: 9781483377445. 
Hamidah, N., \& Nuraishah, A. W. (2017). Faktor-faktor yang mempengaruhi pengguna muslim dalam pembelian produk halal di Kampung Sebatu, Sungai Rambai, Melaka. Journal of Business Innovation, 2(2), 29-44.

Haque, A., Sarwar, A., Yasmin, F., Tarofder, A. K., \& Hossain, M. A. (2015a). Non-Muslim consumers' perception towards purchasing halal food products in Malaysia. Journal of Islamic Marketing, 6(1), 133-147. doi:10.1108/JIMA-04-2014-0033.

Ibrahim, H., \& Hashanah, I. (2015). A generational cohort study of the relationship between religious intensity and religious assurance for the purchase of non-food products. Economics and Financial 5(Special Issue), 330-334. ISSN: 2146-4138.

Ismail, A., \& Yunan, Y. S. (2016). Service quality as a predictor of customer satisfaction and customer loyalty. Scientific Journal of Logistics, 12(4), 269-283 DOI: 10.17270/J.LOG.2016.4.7.

Kamarulzaman, N. H., \& Tarmizi, A. H. (2020). Inbound halal logistics practices: A case of local mosques. Journal of Halal Industry Services, 3(1). a0000167. https://doi.org/10.36877/jhis.a0000167

Khamis, S., Ang, L., \& Welling, R. (2017). Self-branding, 'micro-celebrity' and the rise of Social Media Influencers. Celebrity Studies, 8, 191 - 208.

https://doi.org/10.1080/19392397.2016.1218292.

Khan, A., Mohammad, A. S., \& Muhammad, S. (2020). An integrated model of brand experience and brand love for halal brands: Survey of halal fast food consumers in Malaysia. Journal of Islamic Marketing,Ahead-of-print (No. ahead-of-print). https://doi.org/10.1108/JIMA-11-2019-0236.

Khaniwale, M. (2015). Consumer buying behavior. International Journal of Innovation and Scientific Research, 14(2), 278-286. ISSN 2351-8014.

Kraus, S., Rehman, S., \& Garcia, F. J. S. (2020). Corporate social responsibility and environmental performance: The mediating role of environmental strategy and green innovation. Technological Forecasting and Social Change, 160, https://doi.org/10.1016/j.techfore.2020.120262.

Maichum, K., Parichatnon, S., \& Peng, K. (2017). The Influence of attitude, knowledge and quality on purchase intention towards halal food: A case study of young non-Muslim consumers in Thailand. IRA-International Journal of Management \& Social Sciences, 6(3), 354-364. doi: http://dx.doi.org/10.21013/jmss.v6.n3.p3.

Mathras, D., Cohen, A. B., Mandel, N., \& Mick, D. G. (2015). The effects of religion on consumer behavior: A conceptual framework and research agenda. Journal of Consumer Psychology, 26(2), 298-311. http://dx.doi.org/10.1016/j.jcps.2015.08.001

McCormick, K. (2016). Celebrity endorsements: Influence of a product-endorser match on Millennials attitudes and purchase intentions. Journal of Retailing and Consumer Services, Elsevier, 32(C), 39-45. DOI: 10.1016/j.jretconser.2016.05.012.

Muhamad, N., Leong, V. S., \& Isa, M. N. (2017). Does the country of origin of a halal logo matter? The case of packaged food purchases. Review of International Business and Strategy, 27(4). 484-500. https://doi.org/10.1108/RIBS-06-2017-0049.

Nurhayati, T., \& Hendar, H. (2020). Personal intrinsic religiosity and product knowledge on halal product purchase intention: Role of halal product awareness. Journal of Islamic Marketing, 11(3), 603-620. https://doi.org/10.1108/JIMA-11-2018-0220.

Nuttavuthisit, K., \& Thøgersen, J. (2017). The importance of consumer trust for the emergence of a market for green products: The case of organic food. Journal of Business Ethics, 140(2), 323-337. 
Rehman, S., Bano, T., \& Bhatti, A. (2019). Factors influencing online purchase intention with the mediating role of customer satisfaction. International Journal of Economics, Management and Accounting, 27(1). 235-252.

Rehman, S., Bhatti, A., Mohamed, Mohamed, R., \& Ayoup, H. (2019). The moderating role of trust and commitment between consumer purchase intention and online shopping behaviour in the context of Pakistan. Journal of Global Entrepreneurship Research, 9(43). https://doi.org/10.1186/s40497-019-0166-2.

Rehman, Su., Mohamed, R., \& Ayoup, H. (2018). The mediating role of organizational capabilities between organizational performance and its determinants. (2019). Journal of Global Entrepreneurship Research, 9(30). https://doi.org/10.1186/s40497-019-01555.

Rollins, B., Bhutada, N., Crawford, C., \& Hvizdos, A. (2015). Consumer use of social media for health care and drug information: An exploratory study. PCOM Scholarly Papers, 55(2), e27, https://digitalcommons.pcom.edu/scholarly_papers/1413.

Rusli, N. R. L. (2021). Faktor-faktor penentu pemilihan makanan Halalan Tayyiban dalam kalangan pengguna milenial Muslim di Pulau Pinang [Unpublished doctoral thesis]. Universiti Sains Malaysia.

Saunders, M., Lewis, P., \& Thornhill, A. (2012). Research Methods for Business Students ( $7^{\text {th }}$ ed.). Pearson Education: University of Birmingham.

Sharma, D., \& Ranga, M. (2014). Mobile customer relationship management-A competitive tool. EXCEL International Journal of Multidisciplinary Management Studies, 4(7), 37-42.

Sherwani, M., Ali, A., Ali, A., Hussain, S., \& Zadran, H. G. (2018). Determinants of Muslim consumers' halal meat consumption: Applying and extending the theory of planned behavior. Journal of Food Products Marketing, 24(8), 960-981. DOI: 10.1080/10454446.2018.1450173.

Sudha, M., \& Sheena, K. (2017). Impact of influencers in consumer decision process: the fashion industry. SCMS Journal of Indian Management, 14(3), 14-30.

Wang, S. W., Kao, G. H. -Y., \& Ngamsiriudom, W. (2017). Consumers' attitude of endorser credibility, brand and intention with respect to celebrity endorsement of the airline sector. Journal of Air Transport Management, 60, 10-17. https://doi.org/10.1016/j.jairtraman.2016.12.007

Zakaria, Z., Abdul Majid, M. D., Ahmad Z., Jusoh, Z., \& Zakaria, N. Z. (2017). Influence of halal certification on customers' purchase intention. Journal of Fundamental and Applied Sciences, 9(5S), 772-787. eISSN: 1112-9867. 